\title{
Tool wear rate optimization in PMEDM using titanium powder by Taguchi method for die steels
}

\section{- Banh Tien Long ${ }^{1}$}

- Nguyen Huu Phan ${ }^{2}$

- Ngo Cuong ${ }^{2}$

${ }^{1}$ Hanoi University of Science and Technology, Hanoi, Vietnam

${ }^{2}$ Technical-economics college, Thai Nguyen University, Vietnam

(Manuscript Received on March 08th, 2016, Manuscript Revised May 04th, 2016)

\begin{abstract}
Powder mixed electrical discharge maching

method was applied to the processing parameters (PMEDM) is a complex machining process which is controlled by a number of machining parameters. Each machining parameter has its own influence on performance of the process. For achieving the best performance of the electrical discharge machining (EDM) process, it is crucial to carry out parametric design responses such as Metal Removal Rate (MRR), Tool Wear Rate (TWR) and Surface Roughness(SR). The objective of this paper is to optimization of input parameters for the TWR in PMEDM using to investigate the following: workpiece material, tool material, polarity, pulse-on time, current, pulse-off time, and powder concentration. The analysis used the Taguchi method and given the optimal value for TWR with respective parameters. Electrode material affected the strongest factor, the Taguchi coefficient, S/N of TWR. And the optimal value of TWR was 3.092 $\mathrm{mm}^{3} / \mathrm{min}$. Results from optimization calculations and experimentation have demonstrated high accuracy and efficiency.
\end{abstract} powder titanium are presented. The Taguchi

Keywords: EDM, PMEDM, TWR, Taguchi method, S/N ratio.

\section{INTRODUCTION}

Electric discharge machining (EDM) is one of the most popular machining methods to manufacture dies and press tools because of its capability to produce complicated shapes and machine very hard materials. But the low machining efficiency and poor surface quality are the major drawbacks of this process which restricts its use in mechanical manufacturing. To overcome these drawbacks and to enhance process capabilities researchers did a lot of works, as rotating of electrode, orbiting of electrode, application of ultrasonic vibrations and addition of powders in dielectric fluid of EDM,...

\section{Trang 88}


Past research into powder mixed electric discharge machining (PMEDM) methods have proven promising as methods to improve both the productivity and quality in electric discharge machining (EDM). A suitable powder is mixed into the dielectric fluid used in EDM, which can lead to both an increased MRR and TWR. In addition, SR can be reduced and the microhardness (HV) of the surface machining can be greatly increased. The Productivity and quality of surface machining of EDM can be increased with $\mathrm{Al}$ powder mixed into the dielectric fluid $[1,2]$. Taguchi method has been widely used to optimize quality characteristics in the field of EDM [3]. The Gr powder helped to increase the MRR, while SiC powder helped to reduce the TWR [4]. The results showed that using powder reduces the TWR. Conversely, an increase in current and pulse on time increased the TWR. Taguchi's method was used to evaluate the level of influence of aluminum powder on SR during machining of a H13 workpiece [5]. Negative electrode polarity and $\mathrm{Al}$ powder mixed into the dielectric fluid helped to reduce SR. An optimal value of MRR was determined by Taguchi's method [6]. Powder mixed in the dielectric fluid led to an increased MRR and the maximum value of the MRR obtained was $12.47 \mathrm{~mm}^{3} / \mathrm{min}$ with powder concentrations of $6 \mathrm{~g} / \mathrm{l}$. During the machining of EN31 steel using a PMEDM process, MRR and SR were optimized [7]. The results showed that the MRR and SR were strongly influenced by the concentration of powder and the intensity of electrical discharge. The PMEDM process efficiency was better than that of the EDM process [8]. This contributed to the effectiveness of the PMEDM method. Three different powder materials were used, namely $\mathrm{Gr}$ powder, $\mathrm{SiC}$, and $\mathrm{Al}_{2} \mathrm{O}_{3}$, in the dielectric media. The Gr powder helped to increase the MRR, while $\mathrm{SiC}$ powder helped to reduce the TWR [9]. By using $\mathrm{SiC}$ powder, the productivity of the EDM process improved significantly during the machining of WC [10]. The MRR was increased by $90 \%$ in comparison to the EDM process. The TWR and SR were reduced when mixed powder was added to the dielectric fluid [11].

From the available literature, it was concluded that the few researchers investigated the effect of powder particles mixed in dielectric fluid by taking electrical parameters as process input parameters. But no work is reported on the influence of process input parameters during PMEDM using powder titanium of die steels. The intent of the present study is to study the effect of different input parameters, namely, current, workpiece material, electrode material, electrode polarity, pulse on time, pulse off time and powder concentration and some their interactions on TWR. The effects of various input parameters on output responses have been analyzed using Analysis of Variance (ANOVA). Main effect plot and interaction plot for significant factors and $\mathrm{S} / \mathrm{N}$ ratio have been used to determine the optimal design for each output response.

\section{Experimental procedure}

\subsection{Experimental Equipment}

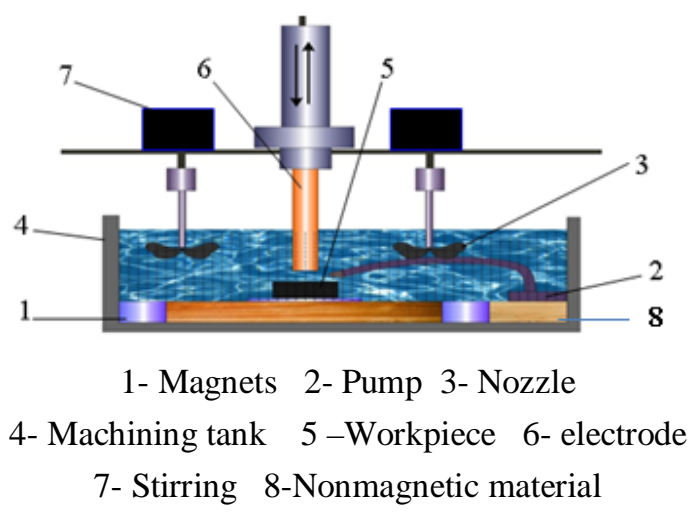

Figure 1. Schematic line diagram 
An electrical discharge machine, AG40L (Sodick, Inc. USA), was used. A schematic experiment is shown in Figure 1. The tank was made of CT3 steel with size 330x180x320 mm and motor shafts were fitted by stirring at 100 $\mathrm{rev} / \mathrm{min}$ with titanium powder were mixed into the dielectric fluid (oil HD-1) during the experiment (see also Figure 1). The workpiece materials included SKD61, SKD11, and SKT4 mound steel, where the common type used in industry standards were selected for this study. Samples measured 45x27x10mm. Furthermore, $\mathrm{Cu}, \mathrm{Gr}$ are among the two materials most commonly used, and have been a focus of recent research. The electrode was shaped into a circular cylinder and it had a diameter measuring $23 \mathrm{~mm}$. The size of the particle of titanium powder measuring $45 \mu \mathrm{m}$ were selected and mixed into the dielectric fluid.

The TWR was calculated by measuring the weight of tool electrode after each machining period. The mass before and after processing was measured with an electronic scale AJ 203 (Shinko Denshi Co. LTD - Japan), where the largest mass measured $200 \mathrm{~g}$, with an accuracy of $0.001 \mathrm{~g}$.

\subsection{Experimental Methods}

\subsubsection{Taguchi Method}

The Taguchi method is used to design experiments based on orthogonal matrix, specific to Taguchi, and is used to assess the process parameters. The experimental parameters could receive more than two levels, including a communication between the different possibilities that exist in an experimental design. The experimental design of Taguchi method was implemented by the orthogonal matrix (table) for placement of the process parameters, which were examined by their levels with the smallest number of experiments during the time as well as the least expensive. The selection of tables was based on the number of parameters and their change rates. ANOVA was based on data obtained from Taguchi's experimental design and was used to select new parameter values to optimize the quality characteristics. To analyze the results of experiments Taguchi used a coefficient, $\mathrm{S} / \mathrm{N}$, to evaluate the impact of interference. The ratio, $\mathrm{S} / \mathrm{N}$, has a greater value for input parameters and was minimally impacted by noise. In experimental studies, the valuation ratio, $\mathrm{S} / \mathrm{N}$, was the highest possible for the results. The Optimal regime of the process parameters was determined by the characteristics of the coefficient S/N [12].

- The higher- the- better:

$(\mathrm{S} / \mathrm{N})_{\mathrm{HB}}=-10 \log \left(\frac{1}{\mathrm{r}} \sum_{i=1}^{r}\left(\frac{1}{y_{i}^{2}}\right)\right)$

Where, $r$ represents some the number of repetitions, and $y_{i}$ is the value of experiment results.

- The Normal - the best:

$(\mathrm{S} / \mathrm{N})_{\mathrm{NB}}=-10 \log \left(\frac{1}{\mathrm{r}} \sum_{i=1}^{r}\left(y_{i}-y_{0}\right)^{2}\right)$

Where, $\mathrm{y}_{0}$ represents the standard values or target values.

- The Lower-the- better:

$$
(\mathrm{S} / \mathrm{N})_{\mathrm{LB}}=-10 \log \left(\frac{1}{\mathrm{r}} \sum_{i=1}^{r} y_{i}^{2}\right)
$$

Where, $\mathrm{y}_{\mathrm{i}}$ is the overall typical value of each experiment.

\section{Trang90}




\subsubsection{Selection of factors and interaction}

In the current study, the interaction effects of the input parameters were considered, as shown in Table 1. In the field of PMEDM, researchers have studied the effect of powder size, workpiece material, electrode material, current, pulse-on time, and pulse-off time. In this study, the interaction terms were considered, specifically workpiece material, $\mathrm{x}$-electrode material $(\mathrm{AXB})$, workpiece material, $\mathrm{x}$-powder concentration $(\mathrm{AxG})$, and electrode material $\mathrm{x}$ powder concentration $(\mathrm{BxG})$.

Table 1. Input parameters and its levels

\begin{tabular}{|c|c|c|c|c|c|c|}
\hline \multirow[t]{2}{*}{ No } & \multirow{2}{*}{ Factors } & \multirow{2}{*}{ Symbols } & \multicolumn{3}{|c|}{ Levels } & \multirow{2}{*}{ DOF } \\
\hline & & & Level 1 & Level 2 & Level 3 & \\
\hline 1 & Workpiece material & A & SKD61 & SKD11 & SKT4 & 2 \\
\hline 2 & Electrode material & $\mathrm{B}$ & $\mathrm{Cu}$ & $\mathrm{Cu}^{*}$ & $\mathrm{Gr}$ & 1 \\
\hline 3 & Polarity & $\mathrm{C}$ & - & + & $-*$ & 1 \\
\hline 4 & Pulse-on time $(\mu \mathrm{s})$ & $\mathrm{D}$ & 5 & 10 & 20 & 2 \\
\hline 5 & Current (A) & $\mathrm{E}$ & 8 & 4 & 6 & 2 \\
\hline 6 & Pulse-off time $(\mu \mathrm{s})$ & $\mathrm{F}$ & 38 & 57 & 85 & 2 \\
\hline 7 & Powder concentration $\mathrm{Ti}(\mathrm{g} / \mathrm{l})$ & $\mathrm{G}$ & 0 & 10 & 20 & 2 \\
\hline 8 & $\begin{array}{l}\text { Interaction of workpiece material and } \\
\text { tool material }\end{array}$ & $\mathrm{AxB}$ & - & - & - & 2 \\
\hline 9 & $\begin{array}{l}\text { Interaction of workpiece material and } \\
\text { powder concentration }\end{array}$ & $A x G$ & - & - & - & 4 \\
\hline 10 & $\begin{array}{l}\text { Interaction of tool material and powder } \\
\text { concentration }\end{array}$ & BxG & - & - & - & 2 \\
\hline 11 & & Total & & & & 20 \\
\hline
\end{tabular}

*- Dummy treated 


\subsubsection{Selection of Orthogonal array and parameter assignment}

Taguchi's orthogonal array's was used for designing the experiments. There are many orthogonal array's available in the Taguchi's method, therefore selection depended upon the number of factors and degrees of freedom of each factor. In this study, seven main factors were considered, out of which, two factors were at two levels, each having one degree of freedom. Five of the main factors had three levels, with each having two degrees of freedom. Also, the study considered three interaction terms. Thus, the total sum of degrees of freedom, including the main factors as well as the interaction terms, was 20 . Therefore, based on the 20 degrees of freedom, the $\mathrm{L}_{27}$ orthogonal array suited the present requirements as it had 26 degrees of freedom. The remaining 6 degrees of freedom were assigned as random error. The 27 trial conditions represented by Taguchi's L27 are given in Table 2 . The dummy treated levels are marked by using * against the repeated level.

Table 2. Experimental design and Results of experiments

\begin{tabular}{|c|c|c|c|c|c|c|c|c|c|}
\hline \multirow{2}{*}{$\begin{array}{l}\text { Exp. } \\
\text { No }\end{array}$} & \multirow{2}{*}{$\begin{array}{c}\text { Workpiece } \\
\text { material }\end{array}$} & \multirow{2}{*}{$\begin{array}{l}\text { Electrode } \\
\text { material }\end{array}$} & \multirow{2}{*}{$\begin{array}{c}\text { Electrode } \\
\text { polarity }\end{array}$} & \multirow{2}{*}{$\begin{array}{c}\text { Pulse } \\
\text { on } \\
\text { time } \\
(\mu s)\end{array}$} & \multirow{2}{*}{$\begin{array}{l}\text { Pulse } \\
\text { curent } \\
\text { (A) }\end{array}$} & \multirow{2}{*}{$\begin{array}{c}\text { Pulse } \\
\text { of } \\
\text { time } \\
(\mu s)\end{array}$} & \multirow{2}{*}{$\begin{array}{c}\text { Powder } \\
\text { concentration } \\
(\mathrm{g} / \mathrm{l})\end{array}$} & \multicolumn{2}{|c|}{ TWR } \\
\hline & & & & & & & & $\overline{T \mathrm{WR}}$ & $\mathrm{S} / \mathrm{N}$ \\
\hline 1 & SKD61 & $\mathrm{Cu}$ & - & 5 & 8 & 38 & 0 & 1,95 & $-5,87$ \\
\hline 2 & SKD61 & $\mathrm{Cu}$ & + & 10 & 4 & 57 & 10 & 2,01 & $-6,85$ \\
\hline 3 & SKD61 & $\mathrm{Cu}$ & $-*$ & 20 & 6 & 85 & 20 & 1,49 & $-3,57$ \\
\hline 4 & SKD61 & $\mathrm{Cu}^{*}$ & + & 10 & 6 & 85 & 0 & 4,42 & $-12,92$ \\
\hline 5 & SKD61 & $\mathrm{Cu}^{*}$ & $-*$ & 20 & 8 & 38 & 10 & 4,36 & $-12,80$ \\
\hline 6 & SKD61 & $\mathrm{Cu}^{*}$ & - & 5 & 4 & 57 & 20 & 0,05 & 24,56 \\
\hline 7 & SKD61 & $\mathrm{Gr}$ & -* & 20 & 4 & 57 & 0 & 11,49 & $-21,21$ \\
\hline 8 & SKD61 & $\mathrm{Gr}$ & - & 5 & 6 & 85 & 10 & 9,93 & $-19,95$ \\
\hline 9 & SKD61 & $\mathrm{Gr}$ & + & 10 & 8 & 38 & 20 & 19,62 & $-25,85$ \\
\hline 10 & SKD11 & $\mathrm{Cu}$ & + & 20 & 4 & 85 & 0 & 2,01 & $-61,87$ \\
\hline 11 & SKD11 & $\mathrm{Cu}$ & -* & 5 & 6 & 38 & 10 & 1,17 & $-14,85$ \\
\hline 12 & SKD11 & $\mathrm{Cu}$ & - & 10 & 8 & 57 & 20 & 3,56 & $-11,03$ \\
\hline 13 & SKD11 & $\mathrm{Cu}^{*}$ & $-*$ & 5 & 8 & 57 & 0 & 2,25 & $-7,34$ \\
\hline 14 & SKD11 & $\mathrm{Cu}^{*}$ & - & 10 & 4 & 85 & 10 & 0,13 & 16,98 \\
\hline 15 & SKD11 & $\mathrm{Cu}^{*}$ & + & 20 & 6 & 38 & 20 & 1,49 & $-3,83$ \\
\hline 16 & SKD11 & $\mathrm{Gr}$ & - & 10 & 6 & 38 & 0 & 7,43 & $-17,67$ \\
\hline 17 & SKD11 & $\mathrm{Gr}$ & + & 20 & 8 & 57 & 10 & 14,07 & $-22,98$ \\
\hline
\end{tabular}

\section{Trang92}




\begin{tabular}{|c|c|c|c|c|c|c|c|c|c|}
\hline 18 & SKD11 & $\mathrm{Gr}$ & $-*$ & 5 & 4 & 85 & 20 & 5,49 & $-14,81$ \\
\hline 19 & SKT4 & $\mathrm{Cu}$ & $-*$ & 10 & 6 & 57 & 0 & 0,58 & 43,49 \\
\hline 20 & SKT4 & $\mathrm{Cu}$ & - & 20 & 8 & 85 & 10 & 5,07 & $-14,11$ \\
\hline 21 & SKT4 & $\mathrm{Cu}$ & + & 5 & 4 & 38 & 20 & 2,90 & $-9,29$ \\
\hline 22 & SKT4 & $\mathrm{Cu}^{*}$ & - & 20 & 4 & 38 & 0 & 0,27 & 10,40 \\
\hline 23 & SKT4 & $\mathrm{Cu}^{*}$ & + & 5 & 6 & 57 & 10 & 4,71 & $-13,49$ \\
\hline 24 & SKT4 & $\mathrm{Cu}^{*}$ & $-*$ & 10 & 8 & 85 & 20 & 4,41 & $-12,92$ \\
\hline 25 & SKT4 & $\mathrm{Gr}$ & + & 5 & 8 & 85 & 0 & 4,53 & $-13,13$ \\
\hline 26 & SKT4 & $\mathrm{Gr}$ & $-*$ & 10 & 4 & 38 & 10 & 9,04 & $-19,20$ \\
\hline 27 & SKT4 & $\mathrm{Gr}$ & - & 20 & 6 & 57 & 20 & 14,58 & $-23,35$ \\
\hline
\end{tabular}

\section{Results and discussion}

\subsection{Result of experiments}

TWR of each sample is calculated from weight difference of tool electrode before and after the performance trial, which is given by (4). The results for TWR for each of the 27 treatment conditions with each experiment was repeated three times. The results were processed by Minitab 17 to determine the mean value of the machining characteristics as well as the coefficient, $\mathrm{S} / \mathrm{N}$. The results are given in Table 3.

$$
T \mathrm{WR}=\frac{T_{i}-T_{f}}{\rho_{T} . t} \cdot 1000 \mathrm{~mm}^{3} / \mathrm{min}
$$

Where

$T_{i}$ - Initial weight of tool electrode $(\mathrm{g})$.

$\mathrm{T}_{\mathrm{f}}$ - Final weight of tool electrode $(\mathrm{g})$.

$\mathrm{t}$ - Time period of trails in minutes $(\mathrm{t}=$ 20min).

$\rho_{\mathrm{T}}$ - Density of tool electrode.

\subsection{Optimal design for TWR}

The $\mathrm{S} / \mathrm{N}$ ratio consolidates several repetitions into one value and is an indication of the amount of variation present. The $\mathrm{S} / \mathrm{N}$ ratios have been calculated to identify the major contributing factors and interactions that cause variation in the TWR. TWR is 'Lower is better' type response which is given by (3).

An analysis of variance (ANOVA) was verified for the signal to noise ratio of both the main and and interaction terms. The $F$ values of the parameters have shown which parameters were the most influential on providing the optimal values of the TWR. Table 3 shows the ANOVA for $\mathrm{S} / \mathrm{N}$ ratio for TWR at $90 \%$ confidence interval. The electrode material $(\mathrm{F}$ value 25.48 ), current ( $F$ value 4.71 ), interaction between workpiece and powder concentration (F value 3.51) factors that affects the TWR. All remaining factors and the interactions are insignificant to affect TWR, table 9. It is observed that the electrode materialis the most significant factor which contributes TWR followed by current and $\mathrm{AxG}$, table 4 . 
Table 3. ANOVA for $\mathrm{S} / \mathrm{N}$ ratio of TWR

\begin{tabular}{|l|c|c|c|c|c|c|}
\hline \multicolumn{1}{|c|}{ Sources } & DOF & SS & V & F & $F_{\text {table }}$ & P \\
\hline Workpiece material (A) & 2 & 29,64 & 14,84 & 0,41 & 3,46 & - \\
\hline Electrode material (B) & 1 & 1567,45 & 1567,47 & $\mathbf{2 5 , 4 8}$ & 3,77 & 40,46 \\
\hline Electrode polarity (C) & 1 & 185,40 & 185,4 & 3,01 & 3,77 & - \\
\hline Pulse on time (D) & 2 & 77,88 & 38,94 & 0,63 & 3,46 & - \\
\hline Current (E) & 2 & 579,67 & 289,86 & $\mathbf{4 , 7 1}$ & 3,46 & 14,82 \\
\hline Pulse of time (F) & 2 & 3,85 & 1,93 & 0,03 & 3,46 & - \\
\hline Powder concentration (G) & 2 & 33,03 & 16,97 & 0,28 & 3,46 & - \\
\hline AxB & 2 & 45,16 & 22,58 & 0,37 & 3,46 & - \\
\hline AxG & 4 & 864,34 & 216,08 & $\mathbf{3 , 5 1}$ & 3,18 & 22,63 \\
\hline BxG & 2 & 19,7 & 9,85 & 0,16 & 3,46 & - \\
\hline Error & 6 & 369,04 & 61,51 & - & - & - \\
\hline Total & 26 & 3775,20 & - & - & - & - \\
\hline e pooled & 19 & 763,7 & 40,19 & - & - & - \\
\hline
\end{tabular}

Table 4. Respone table for $\mathrm{S} / \mathrm{N}$ ratio of TWR

\begin{tabular}{|c|c|c|c|c|c|c|c|}
\hline \multirow{2}{*}{ Level } & \multicolumn{7}{|c|}{ Input parameters } \\
\cline { 2 - 8 } & $\mathrm{A}$ & $\mathrm{B}$ & $\mathrm{C}$ & $\mathrm{D}$ & $\mathrm{E}$ & $\mathrm{F}$ & $\mathrm{G}$ \\
\hline 1 & $-7,597$ & $-3,636$ & $-7,170$ & $-6,760$ & $-2,847$ & $-9,514$ & $-7,733$ \\
\hline 2 & $-9,389$ & $-19,799$ & $-12,729$ & $-9,460$ & $-10,215$ & $-8,595$ & $-10,434$ \\
\hline 3 & $-10,084$ & - & - & $-10,850$ & $-14,008$ & $-8,960$ & $-8,902$ \\
\hline Delta & 2,487 & 16,163 & 5,559 & 4,091 & 11,16 & 0,919 & 2,701 \\
\hline Rank & $\mathbf{6}$ & $\mathbf{1}$ & $\mathbf{3}$ & $\mathbf{4}$ & $\mathbf{2}$ & $\mathbf{7}$ & $\mathbf{5}$ \\
\hline
\end{tabular}

\section{Trang94}




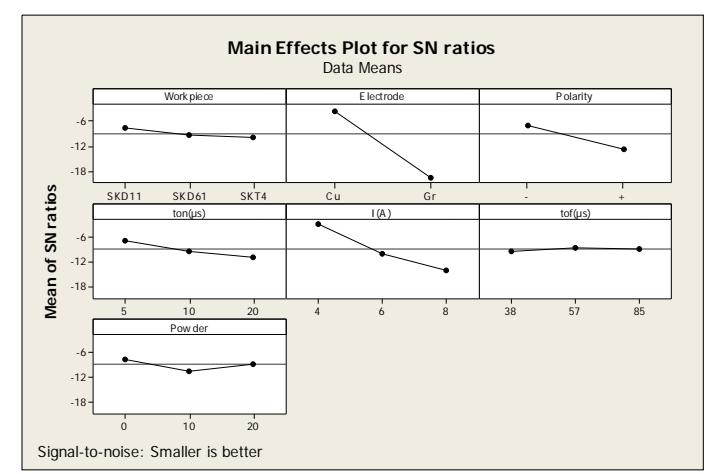

Figure 2. Main effects plot for $\mathrm{S} / \mathrm{N}$ of $\mathrm{TWR}$

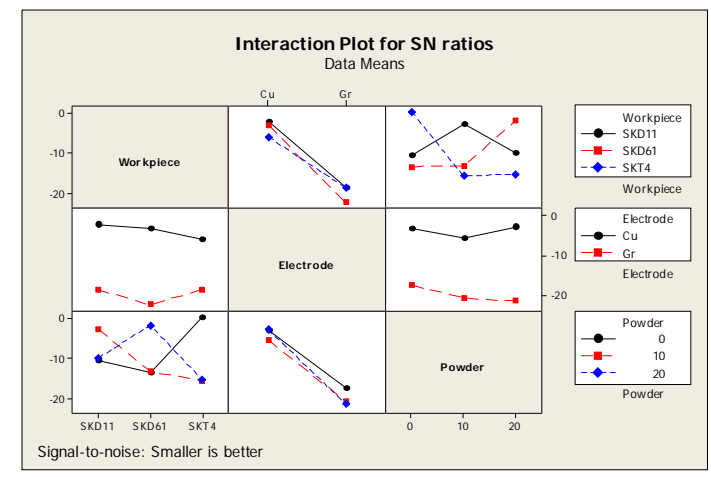

Figure 3. Interaction plot for $\mathrm{S} / \mathrm{N}$ of $\mathrm{TWR}$

The image given in Figure 2 shows the influence of the process parameters on the $\mathrm{S} / \mathrm{N}$ factor of the TWR. These results showed that SKD11 steel materials, copper electrode materials, cathode polarization, time pulse of 5 $\mu \mathrm{s}$, current of $4 \mathrm{~A}$, pulse of $57 \mu$ s downtime, and concentration of titanium powder of $0 \mathrm{~g} / \mathrm{L}$ have a positive influence on the $\mathrm{S} / \mathrm{N}$ factor of the TWR. These parameters greatly impacted the optimal results of the TWR. The image shown in Figure 3 illustrates the influence of the interaction between the parameters on the S/N of the TWR. Results indicated that interaction of SKD11 steel with $\mathrm{Cu}$ electrode materials, the interaction of SKT4 steel with titanium powder concentration of $0 \mathrm{~g} / \mathrm{L}$, the interaction of the $\mathrm{Cu}$ electrode materials with titanium powder concentration of
$20 \mathrm{~g} / \mathrm{L}$ were the interactions with the strongest influence on the $\mathrm{S} / \mathrm{N}$ factor of the TWR.

Estimated value of the $\overline{T \mathrm{WR}}$ at optimal conditions: Reasonable process parameters of the TWR consisted of the following: A2, B1, C1, D2, E1, F2, and G2, of which two electrode material parameters (B) and current $(\mathrm{E})$ had a strong influence on the TWR. The TWR's value was determined by the formula given in equation (5):

$$
\mu_{B_{2}, E_{3}, G_{1}, B_{2} \times G_{1}}=\overline{T W R}_{o p}=\bar{B}_{1}+\bar{E}_{1}+\overline{A_{3} \times G_{3}}-2 \times \bar{T}
$$

In this equation, $\overline{B_{1}}=2.383 \mathrm{~mm}^{3} / \mathrm{min}$; $\overline{E_{1}}=3.713 \mathrm{~mm}^{3} / \mathrm{min} ; \quad \overline{A_{3} \times G_{3}}=$ $\mathrm{mm}^{3} / \mathrm{min} ; \bar{T}=5.152 \mathrm{~mm}^{3} / \mathrm{min}$. Consequently, $\overline{T \mathrm{WR}}_{o p}=2.383+3.713+7.30-2 \times 5.152$ $=3.092 \mathrm{~mm}^{3} / \mathrm{min}$.

Furthermore, the predicted confidence interval for the confirmation experiments was $0.69 \mathrm{~mm}^{3} / \mathrm{min} \leq \overline{T W R}_{\text {op }} \leq 5.492 \mathrm{~mm}^{3} / \mathrm{min}$ with $C I_{C E}= \pm 2.4$. Additionally, the $90 \%$ confidence interval of the population was $2.542 \mathrm{~mm}^{3} / \mathrm{min} \leq$ $\overline{T \mathrm{WR}}_{\text {op }} \leq 3.642 \mathrm{~mm}^{3} / \mathrm{min}$ with $C I_{P O P}= \pm 0.55$.

Confirmation Experiments: Confirmation Experiments were conducted with the process parameters determined through calculations of the SKD11 workpiece material, the $\mathrm{Cu}$ electrode, the electrode polarization agreement, pulse duration of $10 \mu \mathrm{s}$, a current of $4 \mathrm{~A}$, the horizontal development pulse of $57 \mu$ s, and powder concentration of $10 \mathrm{~g} / \mathrm{L}$. The results of the TWR $=2,93 \mathrm{~mm} 3 / \mathrm{min}$, and the difference between the calculated results and the experimental results was $4.1 \%$. 


\section{CONCLUSIONS}

From the experimental work, an optimal set of process variables that yields the optimum quality features to machined parts produced by PMEDM using tiatanium powder has also been obtained. The use of the Taguchi method to optimize individual quality TWR of machining process was refined by. In $\mathrm{S} / \mathrm{N}$ ratio, the electrode material is the most significant in affecting TWR followed by current, interaction between workpiece and powder concetration. The best results for TWR would be suggested if SKD11 workpiece machined at current 4 Amp and pulse on time10 $\mu \mathrm{sec}$ and pulse of time $57 \mu$ s, with copper electrode and powder concentration of $10 \mathrm{~g} / \mathrm{l}$. The mean value with $90 \%$ confidence interval was found to be $3.092 \pm 0.55 \mathrm{~mm}^{3} / \mathrm{min}$. The optimal sets of process parameters were obtained for various performance measures using Taguchi"s design of experiment methodology. The summary results of predicted optimal values of the responses and their confidence intervals (both for confirmation experiment and population).

\section{Tối ưu hóa lượng mòn điện cực trong PMEDM sử dụng bột Titan bằng phương pháp Taguchi khi gia công thép làm khuôn}

- Bành Tiến Long ${ }^{1}$

- Nguyễn Hũ̃u Phấn ${ }^{2}$

- Ngô Cường ${ }^{2}$

${ }^{1}$ Trường Đại học Bách khoa Hà Nội

${ }^{2}$ Trường Cao đẳng Kinh tế - Kỹ thuật, ĐH Thái Nguyên

\section{TÓM TẮT}

Gia công tia lưa điện với dung dịch điện môi có trộn bột (PMEDM) là một công nghệ phức tạp. Phuong pháp này được điều khiển bởi rất nhiều các thông số công nghệ. Trong đó, mỗi thông số có ảnh huởng khác nhau đến chất luợng của quá trình gia công. Chất luợng của quá trình gia công tia lưa điện (EDM) được đánh giá bởi các đặc trung công nghệ nhu: năng suất gia công (MRR), luợng mòn điện cưc (TWR) và nhấp nhô bề mặt
$\left(R_{a}\right)$. Trong bài báo này, TWR trong PMEDM sủ dụng bột Titan là đối tương được tối ưu hóa. Phuoong pháp Taguchi được sử dụng để đánh giá ảnh hưởng của các thông số công nghệ: vật liệu điện cưcc, vật liệu phôi, sư phân cưc điện cưc, thời gian phát xung, thời gian ngùng phát xung, cuờng độ dòng điện và nồng độ bột Titan. Phân tích Taguchi đã xác định được TWR tối uu với trị số công nghệ tuoong ứng thông qua hệ số $S / N$ của

\section{Trang96}


nó. Vật liệu điện cực là thông số có ảnh hưởng mạnh nhất đến hệ số S/N của TWR. Trị số tối ưu $R_{\text {atoiuu }}=3,092 \mathrm{~mm}^{3} /$ phút và kết quả tối ưu đã được thục nghiệm kiểm chưng cho độ chính xác phù hơp.

Tù khóa: EDM; PMEDM; TWR, Phuơng pháp Taguchi; Hệ số S/N.

\section{REFERENCES}

[1]. P. Singh, A. L. Kumar, N. Beri, V.Kumar, 2010a,"Influence of electrical parameters in Powder mixed electric discharge machining (pmedm) of hastelloy", Journal of Engineering Research and Studies, 1, pp.93105.

[2]. H.K. Kansal, S. Singh, P. Kumar, 2007, "Effect of Silicon Powder Mixed EDM on Machining Rate of AISI D2 Die Steel”, Journal of Manufacturing Processes, 9(1).

[3]. C. R. Dr. Sanghani, G. D. Acharya, 2014, "A Review of Research on Improvement and Optimization of Performance Measures for Electrical Discharge Machining", Int. Journal of Engineering Research and Applications, 4(1), pp. 433-450.

[4]. V. Parkash, D. Kumar, 2013, Effect of Powder Mixed Dielectric Medium on Tool Wear Rate in EDM, International journal of scientific research(IJSR), 2 (2), pp.107-109.

[5]. G. Singh, P. Singh, G. Tejpal, B. Singh, 2012, "Effect of machining parameters on surface roughness of H13 Steel in EDM process using powder mixed fluid", International Journal of Advanced Engineering Research and Studies, 2(1), pp.148-150.

[6]. M. Rajendra, G. K. M. Rao, 2014, "Experimental evaluation of performsnce of electrical discharge machining of D3 die steel with $\mathrm{Al} 2 \mathrm{O} 3$ abrasive mixed dielectric material by using design of experiments", International Journal of Scientific
Engineering and Technology, 3, pp. 599606.

[7]. V. Kumar, Mr. Rajpal, M. Singh, 2014, "Experimental Study of Surface Parameters of EN31 on Powder Mixed EDM using Taguchi Methodology", International Journal for Scientific Research \& Development, 2(07), pp. 122-125.

[8]. M. A. Razak, A. M. Abdul-Rani, and A. M Nanimina, 2015, "Improving EDM Efficiency with Silicon Carbide PowderMixed Dielectric Fluid", International Journal of Materials, Mechanics and Manufacturing, 3(1), pp.40-43.

[9]. M. G. Rathi, D. V. Mane, 2014, "Study on Effect of Powder Mixed dielectric in EDM of Inconel 718", International Journal of Scientific and Research Publications, 4(11), pp.1-7.

[10].S. Y. Kaldhone, M. V. Kavade, U. Rawat, 2014, "Effect of Powder Mixed Dielectric on Performance Measures of EDM for Tungsten Carbide", International Journal of Innovative Research in Advanced Engineering (IJIRAE), 1(10), pp. 106-111.

[11].P. Singh, A. Kumar, N. Beri, V. Kumar, 2010b, "Some Experimental investigation on aluminum powder mixed EDM on machining performance of hastelloy steel", International Journal of Advanced Engineering Technology, 1, pp. 28-45.

[12].R. Roy, 1990, "A Primer on the Taguchi Method", New York : Van Nostrand Reinhold. 